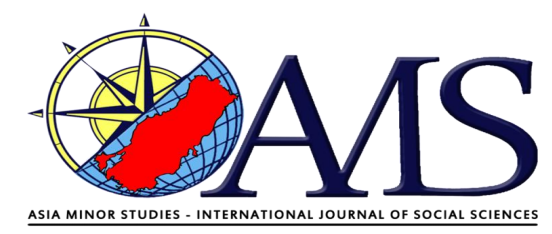

Cilt: 6, Sayı: AGP Özel SayısI, Ekim 2018 / Volume: 6, Issue: AGP Special Issue , October 2018

\title{
ÖZEL BANKA ÇALIŞANLARININ ÖRGÜTSEL BAĞLILIK DÜZEYLERİ
}

Organizational Commitment Levels Of Private Banking Employees

\author{
Pınar UÇAR* \\ Sabahat BAYRAK KÖK **
}

\begin{abstract}
ÖZ
Örgütsel bağlılık, çalışanların örgütün hedef ve değerlerini benimsemesi, örgüt yararına fazla olarak çaba harcaması ve örgütte kalma arzusudur. $\mathrm{Bu}$ çalışmada örgütsel bağlılık; duygusal bağl11ık, normatif bağl1lık ve devam bağl1lı̆̆ olmak üzere üç boyutta ele alınmıştır. Bu çalışmanın amacı, ilk olarak özel banka çalışanlarının örgütsel bağlılık boyutlarına ilişkin ortalama ve standart sapma değerlerine yer vermektir. Ayrıca çalışanların örgütsel bağlılık boyutlarına ilişkin algılarının cinsiyet, yaş, medeni durum, eğitim durumu, unvan ve çalışma süresine göre değişip değişmediği belirlemektir. Bu kapsamda çalışmada örgütsel bağlılık boyutlarının demografik özelliklere göre farklılık gösterip göstermediği t testi ve Anova ile test edilmiştir. Araştırma sonucuna göre, çalışanların örgütsel bağlılık boyutlarına yönelik algıları medeni duruma, yaşa, eğitim durumuna, unvana ve çalışma süresine göre farklılık göstermektedir.
\end{abstract}

Anahtar Kelimeler: Örgütsel bağlılık, Örgütsel bağlılık boyutları

\begin{abstract}
Organizational commitment is to adopt the objectives and values of organization by employees, spending extra effort for the benefit of organizations and desire to remain in the organization. In this study, organizational commitment handled in three dimensions which is included affective commitment, continuance commitment, normative commitment. The purpose of this study is to firstly include the mean and standard deviation values of organizational commitment dimensions of private bank employees. In addition, it is determined whether the perceptions of

\footnotetext{
**öğrt. Gör. Antalya Akev Üniversitesi, Bankacılık ve Sigortacılık, pinar.ucar@akev.edu.tr ***Prof. Dr. Pamukkale Üniversitesi, İktisadi ve İdari Bilimler Fakültesi, İşletme Bölümü, sbayrak@pau.edu.tr
} 


\section{Özel Banka Calıșanlarının Örgütsel Bağlılık Düzeyleri}

employees' organizational commitment dimensions change according to gender, age, marital status, education status, title and duration of work. In this context, the study was tested by t-test and ANOVA to showing whether the significant difference in the perception of organizational commitment dimension according to demographic factors. According to the research result, employees' perceptions about organizational commitment dimensions differs from according to marital status, age, education level, title and duration on work.

Keywords: Organizational commitment, organizational commitment dimensions

\section{Giriş}

Değişken olan bu sosyal ve ekonomik zamanlarda, örgütsel çevreler hızla değişmekte, rekabet artmakta ve entelektüel sermayenin önemi her geçen gün artmaktadır. Sadece hızla değişen çevreye ayak uyduran örgütler hayatta kalabilmektedir (Chen vd., 2010: 248). Bu noktada, örgütlerin dünya çapındaki rekabet ile başa çıkabilmeleri için insan kaynağına gereken önemi vermesi ve onları örgütte tutmanın yollarını araması gerekmektedir. Bunu sağlamanın yolu ise, çalışanların örgüte olan bağlılıklarını sağlamaktır (Özdevecioğlu, 2003: 115). Örgütsel bağlılık çalışanların örgütün hedeflerini benimsemesi, amaçlara ulaşma noktasında çaba sarf etmeleri, örgütte kalma konusunda istekli olmaları ve örgüte karşı sadakat duymalarıdır.

$\mathrm{Bu}$ çalışmanın amacı bankacılık sektöründe özel bankalarda çalışanların örgütsel bağlılık düzeylerini ortaya koymaktır. Ayrıca örgütsel bağlılık boyutlarının sorularına ilişkin ortalamaları ortaya koymak ve sonuçlar neticesinde önerilerde bulunmaktır. Çalışanların örgütsel bağlılık algılarının demografik değişkenlere göre farklılık gösterip göstermediği de test edilmiştir.

\section{1. Örgütsel Bağlılık}

Bağl1lık, en yüksek derecede bir duyguyu ifade etmektedir. Bir kuruma, kişiye, düşünceye, kendimizden daha büyük gördüğümüz bir şeye bağlılık duyma, yerine getirmek zorunda olduğumuz bir yükümlüğü anlatmaktadır (Balay, 2014: 15). Örgütsel bağlılık ise, bireyin örgüte dahil olma, sadakat duyma ve örgütsel değerlere olan inanç gibi unsurları kapsayan psikolojik bağlılık ve kendini tam anlamıyla işe verme anlamına gelmektedir (Güney, 2001: 138). Örgütsel bağlılığa yönelik pek çok tanım yapılmasına karşın en fazla kabul gören ve kullanılan tanım Porter ve arkadaşlarına (1974) aittir. Bu tanıma göre bağlılık üç faktörle karakterize edilmiştir (Mowday et al., 1979: 226): örgütün amaç ve değerlerini kabul etme ve güçlü bir inanç duyma, örgüt adına kayda değer bir çaba gösterme konusunda istekli olma, örgüt üyeliğini sürdürmek için güçlü bir istek duymadır.

Örgütsel bağlılık ilk olarak Whyte (1950) tarafından bireylerin sadakatini ve bağlılığını sadece örgütte çalışmak olarak değil ayrıca örgüte ait olma hissi olarak da tanımlaması ile ele alınmıştır. 1960'lı yıllardan sonra bağlılık iş yeri literatürü 


\section{Özel Banka Calıșanlarının Örgütsel Bağlılık Düzeyleri}

içinde daha fazla ilgi çeken bir kavram haline gelmiştir. Bu anlamda Becker (1960) çalışanların sadakatine odaklanmış, bireylerin tutarlı davranışlar sergilemesinin nedenini örgüte yaptı̆̆ yatırımlar (yan bahis) ve örgütten ayrılması durumunda tüm bunları kaybetmeyi istememesi olarak ifade etmiştir. 1970 yılı başları ve 1980 yılının ortalarına kadar bağlılığın tutumsal yönüne odaklanılmış ve bağlılık üzerine pek çok araştırma yapılmıştır. Steers, 1970 yılında bağlılığın verimliliğge etkisini ve 1976 yılındaki çalışmasında işgücü devir oranı ve örgütsel bağlılık arasındaki ilişkiyi incelemiştir. 1980 ortaları ve 2000 yılları arasında araştırmacılar bağlılığın çoklu yönünü keşfetmişlerdir. Örneğin Morrow'un (1983), Reichers'in (1985) ve T. E. Becker'ın (1992) çalışmaları çoklu bağl1lık hedeflerinin temelini oluşturmaktadır. Allen ve Meyer'ın (1991) örgütsel bağlılığı; duygusal, normatif ve devam bağlllı̆̆1 olmak üzere üçe ayırmıştır.

\section{Örgütsel Bağlılık Boyutları}

Örgütsel bağl1lı̆̆ın ilk sınıflandırmaları O'Reilly ve Chatman (1986), Etzioni (1961) ve Kanter (1968) tarafindan yapılmıştır. Her ne kadar bu zamana kadar bazı sınıflandırmalar yapılsa da Allen ve Meyer'ın (1991) ortaya koyduğu hâlâ geçerliliğini koruyan örgütsel bağlılık; duygusal, normatif ve devam bağlılığı olmak üzere üç boyutta ele alınmaktadır.

Duygusal Bağlılık: Tutumsal kaynaklı olan duygusal bağl1lık, literatürde en sık rastlanan ve ilgi gören bağll1ık türüdür. Duygusal bağl1lık, çalışanların örgütsel amaçları, hedefleri, stratejileri, ilkeleri, politikaları, kuralları, norm ve değerleri benimsemesi onlarla özdeşim kurması, örgütün faaliyetlerini ve işlemlerini desteklemesi, örgütle bir anlamda kimlik özdeşliği kurması olarak tanımlanmaktadır (Eren, 2012: 556). Ayrıca duygusal bağlılık, çalışanların duygusal olarak örgüte bağlanmasını, örgüt yararına beklenenden fazla çaba sarf etmesini, fedakarlıkta bulunmasını ve kendilerini örgütün bir parçası olarak hissetmelerini ve görmelerini ifade etmektedir (Robbins ve Judge, 2012: 77).

Normatif Bağll1ık: Normatif bağlılık çalışanın kendisini çalıştığı örgüte karşı sorumlu hissetmesi, bu sorumluluk dolayısıyla yerine getirmesi gereken görevleri olduğunun bilincinde olması ve bunu benimsemesi, böylelikle çalışanın örgüt üyeliğini sürdürme noktasında zorunluluk duyduğu bir bağl1lık türüdür (Sevinç ve Şahin, 2012: 267). Wiener'e (1982) göre, normatif bağllılıta çalışanlar ahlaki zorunluluk hissinden dolayı örgütte kalmaya devam etmekte ve bu konuda gönüllü olmaktadır (Tett ve Meyer, 1993: 262). Allen ve Meyer’a (1990) göre normatif bağll1ık, bireyin hem örgüte girmeden önce yaşamış olduğu kültürel ve ailesel sosyalleşmeden hem de örgüte girişi sonrasındaki örgütsel sosyalleşme sürecinden etkilenmektedir. Bu bir anlamda kişilerin sahip olduğu örgütsel bağlllık normunu ifade etmektedir. Örgütsel bağlılık normu ise çalışanın güçlü kişisel bağl11ık duygusuyla örgütüne duyduğu bağll1ıktır (Balay, 2014: 87-88).

Devam Bağlılı̆ı: Devam bağlllığı, Allen ve Meyer'in Becker'in "Yan Bahis" kuramından hareketle geliştirdiği ve zorunlu bağlllık olarak da anılan bir kavramdır. Devam bağlılığı çalışanların örgütten sağladıkları maddi ve psiko-sosyal çıkarlara bağlı olarak ortaya çıkan bir bağlılık türüdür. Bu bağlılık türünde bireylerin 


\section{Özel Banka Calıșanlarının Örgütsel Bağlılık Düzeyleri}

örgütte kalmalarının nedeni örgüte yaptıkları yatırımlarla birlikte tüm faydalardan vazgeçme maliyetidir. Bu yatırımlar çalışanların iş arkadaşlarıyla olan yakın ilişkisi, aldığı kıdemler, emeklilik yatırımları, özel yetkiler ve kariyer gibi örgütte çalıştığı zaman boyunca aldı̆̆ yatırımlardır (Allen ve Meyer, 1984: 373, Çelik, 2008: 140).

\section{Araştırma}

Bu bölümde, kuramsal temelleri açıklanan örgütsel bağlılığa yönelik algılar, ampirik bir araştırmayla değerlendirmeye tabi tutulacaktır. $\mathrm{Bu}$ anlamda, bu başlık altında araştırmanın amacı, yöntemi ve bulguları ele alınacak, sonuç ve önerilerle bölüm sonlanacaktır.

\subsection{Araştırmanın Amacı}

$\mathrm{Bu}$ araştırmada özel bankalarda örgütsel bağll11k konusunun bir bütün olarak ele alınması ve özel banka çalışanlarının bu konuya yönelik algılarının ortaya konulması amaçlanmıştır. Bu noktada bu çalışmanın amacı Denizli il merkezinde görev yapan özel banka çalışanlarının örgütsel bağl1lık düzeylerini belirlemektir. $\mathrm{Bu}$ amaca ulaşmak için şu sorulara yanıt aranmıştır:

1. Özel banka çalışanlarının örgütsel bağlılık düzeyleri nasıldır?

2. Özel banka çalışanlarının örgütsel bağlılık düzeyleri cinsiyet, eğitim durumu, yaş, kıdem değişkenlerine göre değişmekte midir?

\subsection{Araştırmanın Yöntemi}

Araştırmanın evrenini Denizli merkezde faaliyet gösteren özel bankalar oluşturmaktadır. Bilgi edinme kanunu çerçevesinde Bankalar Birliğinden Denizli'nin merkez ve ilçelerinde sadece özel bankalardaki çalışan sayısına yönelik olarak ayrıntılı ve detaylı bilgi edinilemediğinden özel bankalarla yapılan görüşmeler sonunda merkez ilde toplam 830 çalışanın görev yaptığına ulaşılmıştır. En küçük örneklem hacmini bulmak için basit tesadüfi örnekleme yöntemi kullanılmışıır. Araştırma kapsamında Denizli merkezde bulanan özel statülü bankalarda çalışanlara anket elden dağıtılmış ve elden toplanmıştır. Toplamda 250 banka çalışanına anket dağıtılmış, 191 tanesi geri dönmüş ancak geri dönen anketlerden 10 tanesi tüm sorulara aynı yanıtın verilmesi, soruların eksik olarak cevaplandırılması gibi sebeplerden analize dahil edilmeyip çıkarılmıştır. Geriye kalan 181 anket araştırmaya dahil edilmiştir. Geri dönüş oranı \%72,4'tür. Araştırmadan elde edilen veriler araştırma evrenini $\% 95(\alpha=.05)$ güven düzeyinde temsil etmektedir. Örgütsel bağlllığı seviyesini ölçmek için Meyer ve Allen (1991) tarafindan geliştirilen Wasti (2000) tarafindan geçerliliği ve güvenilirliği test edilmiş olan "Örgütsel Bağlılık Ölçeği” kullanılmıştır.

\subsection{Araştırma Bulguları}

18 ifadeden oluşan örgütsel bağlllık ölçeğinin güvenirliğini test etmek için Cronbach Alfa kullanılmıştır. Tüm ölçeğin güvenirliği 0,765 olarak tespit edilmiştir. Örgütsel bağlılığın duygusal, normatif ve devam bağlılığ bulunmaktadır. Duygusal bağlılık boyutunun güvenirliği 0,913 , normatif bağlılığın 


\section{Özel Banka Calıșanlarının Örgütsel Bağlılık Düzeyleri}

güvenirliği 0,862 ve devam bağl1lığının güvenirliği 0,714 olarak hesaplanmıştır. Tüm cronbach alfa değerlerine bakıldığında ölçeğin güvenilir olduğu söylenebilir.

Ölçeklerin yapısal geçerliliklerini ölçmek için faktör analizi yapılmıştır. Ancak öncesinde toplanmış olan verilerin faktör analizine uygun olup olmadığının tespit edilmesinde KMO (Kaiser-Meyer-Olkin) ve Barlett testleri uygulanmıştır. Yapılan faktör analizi sonucunda örgütsel bağlllık ölçeğinin Kaiser-Meyer-Olkin (KMO) değeri 0,902 çıkmıştır. Bu değerin 0.50 'in üzerinde olması verilerin faktör analizi için elverişli olduğunu gösterir. Barlett sig değeri $\left(p=0,000, \chi^{2}=1283,601\right.$, $\mathrm{p}<0.01)$ de anlamlı çıkmıştır. Ayrıca, ortaya çıkan yapı toplam varyansın $\% 63,870$ 'ini açıklamaktadır. Bu çalışmada 15 ifade ile yapılan faktör analizi sonucunda ölçeğin aslına uygun olarak üç faktör ortaya çıkmıştır. Ortaya çıkan faktörler ve faktör yükleri Tablo 1'de gösterilmektedir.

Tablo 1: Örgütsel Bağlılık Ölçeği Faktör Yükleri

\begin{tabular}{|c|c|c|c|}
\hline \multirow[b]{2}{*}{ İFADELER } & \multicolumn{3}{|c|}{ BOYUTLAR } \\
\hline & $\begin{array}{l}\text { Duygusal } \\
\text { Bağlilik }\end{array}$ & $\begin{array}{l}\text { Normatif } \\
\text { Bağlilik }\end{array}$ & $\begin{array}{l}\text { Devam } \\
\text { Bağlilığ }\end{array}$ \\
\hline $\begin{array}{l}\text { Bu kuruluşa kendimi "duygusal olarak } \\
\text { bağllı" hissetmiyorum. }\end{array}$ &, 822 & & \\
\hline $\begin{array}{l}\text { Kuruluşuma karşı güçlü bir aitlik hissim } \\
\text { yok. }\end{array}$ &, 818 & & \\
\hline $\begin{array}{l}\text { Kendimi kuruluşumda "ailenin bir parçası" } \\
\text { gibi hissetmiyorum. }\end{array}$ &, 816 & & \\
\hline $\begin{array}{l}\text { Meslek hayatımın kalan kısmını bu } \\
\text { kuruluşta geçirmek beni çok mutlu eder. }\end{array}$ &, 705 & & \\
\hline $\begin{array}{l}\mathrm{Bu} \text { kuruluşun meselelerini gerçekten de } \\
\text { kendi meselelerim gibi hissediyorum. }\end{array}$ &, 671 & & \\
\hline $\begin{array}{l}\text { Bu kuruluşun benim için çok kişisel (özel) } \\
\text { bir anlamı var. }\end{array}$ &, 670 & & \\
\hline $\begin{array}{l}\text { Buradaki insanlara karşı yükümlülük } \\
\text { hissettiğim için kuruluşumdan şu anda } \\
\text { ayrılmazdım. }\end{array}$ & &, 842 & \\
\hline Kuruluşuma çok şey borçluyum. & &, 625 & \\
\hline Bu kuruluş benim sadakatimi hak ediyor. & &, 634 & \\
\hline $\begin{array}{l}\text { Kuruluşumdan şimdi ayrilsam kendimi } \\
\text { suçlu hissederim. }\end{array}$ & &, 595 & \\
\hline
\end{tabular}




\section{Özel Banka Calıșanlarının Örgütsel Bağlılık Düzeyleri}

Benim için avantajlı da olsa kuruluşumdan şu anda ayrılmanın doğru olmadığını hissediyorum.

$\mathrm{Bu}$ kuruluştan ayrılmanın az sayıdaki olumsuz sonuçlarından biri alternatif iş olanaklarının az olmasıdır.

$\mathrm{Bu}$ kuruluşu bırakmayı düşünemeyeceğim kadar az seçeneğim olduğunu düşünüyorum.

Şu anda kuruluşumdan ayrılmak istediğime karar versem, hayatımın çoğu altüst olur.

Eğer bu kuruma bu kadar emek vermemiş olsaydım, başka yerde çalışmayı



Araştırmaya katılanların ölçekteki sorulara verdikleri cevaplara ilişkin ortalamalar ve standart sapma değerleri Tablo 2'de yer almaktadır. Analiz sonuçlarından görüldüğü üzere duygusal bağlllık $(\overline{\mathrm{x}}=3,75)$ ve normatif bağlllığa $(\overline{\mathrm{x}}=$ $3,48)$ ilişkin ortalama düzeyleri yüksek, devam bağlllı̆g $1(\bar{x}=2,95)$ için orta düzeydedir.

Tablo 2: Örgütsel Bağlılık Ölçeğine İlişkin Ortalama ve Standart Sapma

Değerleri

\begin{tabular}{llll}
\hline & Ortalama $(\overline{\mathrm{x}})$ & Standart Sapma & \multicolumn{1}{c}{ Düzey* } \\
\hline Örgütsel Bağl1lık & 3,39 & 1,09452 & Orta \\
\cline { 2 - 4 } Duygusal Bağll1ık & 3,75 & 1,07562 & Yüksek \\
Devam Bağl1lığı & 2,94 & 1,16140 & Orta \\
Normatif Bağlılık & 3,48 & 1,04655 & Yüksek \\
\hline
\end{tabular}

* $\overline{\mathrm{x}}=1-2.59$; Düşük, $\overline{\mathrm{x}}=2,60-3.39$; Orta, $\overline{\mathrm{x}}=3.40-5$; Yüksek.

Tablo 3'de görüldüğü üzere, örgütsel bağl1lıkla ilgili değerler, cinsiyete göre farkl11lk göstermemekte; medeni duruma, yaşa, eğitim durumuna, unvana ve çalışma süresine göre farklılık göstermektedir $(\mathrm{p}<0,05)$. Buna göre evlilerin duygusal bağlılıkları bekarlara göre daha yüksektir. Bu da evli çalışanların bekar çalışanlarla karşılaştırıldığında kurumun değer ve hedeflerini daha çok benimseyerek görevlerini yerine getirdiklerini, kuruma olan aidiyet duygusunun daha fazla olduğunu göstermektedir. 41-50 yaş grubunun duygusal bağlılık ve 


\section{Özel Banka Calıșanlarının Örgütsel Bağlılık Düzeyleri}

normatif bağl1lık ortalamasının 20-30 yaş grubuna ve 31-40 yaş grubuna göre daha yüksek olduğu görülmektedir. Bir başka analiz sonucuna göre, eğitim düzeyi lisansüstü olan katılımcıların duygusal bağlllık algıları eğitim düzeyi lise olan çalışanlara göre daha yüksektir. Ayrıca, eğitim düzeyi lise olan katılımcıların ise eğitim düzeyi lisans olan katılımcılar ile kıyaslandığında devam bağlılığı daha yüksektir. Araştırmada asistan servis görevlisinin yönetmen ile kıyaslandığında duygusal bağlılığının daha düşük, devam bağlılığının ise daha yüksek olduğu sonucuna ulaşılmıştır. Son olarak, çalışma süresi 1 yıldan az olan çalışanların devam bağlığının en yüksek, çalışma süresi 6-10 yıl aralığında olan çalışanların ise devam bağlllı̆̆ının en düşük olduğu tespit edilmiştir.

Tablo 3: Örgütsel Bağlılık Algılarının Demografik Değişkenlere Göre Karşılaştırılması

\begin{tabular}{|c|c|c|c|c|}
\hline Boyut & Cinsiyet & Ortalama & $\begin{array}{l}\text { Standart } \\
\text { Sapma }\end{array}$ & Sig $(p)$ \\
\hline \multirow{2}{*}{$\begin{array}{l}\text { Duygusal } \\
\text { Bağll11k }\end{array}$} & Kadın & 3,7079 &, 85966 & \multirow[b]{2}{*}{0,495} \\
\hline & Erkek & 3,7996 & ,94592 & \\
\hline \multirow{2}{*}{$\begin{array}{l}\text { Normatif } \\
\text { Bağl1lık }\end{array}$} & Kadın & 3,4201 & ,79266 & \multirow[b]{2}{*}{0,564} \\
\hline & Erkek & 3,4911 &, 85768 & \\
\hline \multirow{2}{*}{$\begin{array}{l}\text { Devam } \\
\text { Bağl1lığ1 }\end{array}$} & Kadın & 2,9046 &, 78763 & \multirow{2}{*}{0,517} \\
\hline & Erkek & 2,9851 & ,88184 & \\
\hline Boyut & $\begin{array}{l}\text { Medeni } \\
\text { Durum }\end{array}$ & Ortalama & $\begin{array}{l}\text { Standart } \\
\text { Sapma }\end{array}$ & $\operatorname{Sig}(p)$ \\
\hline \multirow{2}{*}{$\begin{array}{l}\text { Duygusal } \\
\text { Bağl1l1k }\end{array}$} & Bekar & 3,5312 & ,90026 & \multirow[b]{2}{*}{0,049} \\
\hline & Evli & 3,8296 & ,88916 & \\
\hline \multirow{2}{*}{$\begin{array}{l}\text { Normatif } \\
\text { Bağl1lık }\end{array}$} & Bekar & 3,3229 & ,72007 & \multirow[b]{2}{*}{0,202} \\
\hline & Evli & 3,5000 & 85336 & \\
\hline \multirow[t]{2}{*}{ Devam Bağl1lığ } & Bekar & 3,1146 & ,74011 & \multirow[b]{2}{*}{0,093} \\
\hline & Evli & 2,8797 & 85591 & \\
\hline Boyut & Yaş & Ortalama & $\begin{array}{l}\text { Standart } \\
\text { Sapma }\end{array}$ & $\operatorname{Sig}(p)$ \\
\hline \multirow{4}{*}{$\begin{array}{l}\text { Duygusal } \\
\text { Bağl1lik }\end{array}$} & $20-30$ & 3,4493 & 89709 & \multirow{4}{*}{, 002} \\
\hline & $31-40$ & 3,7381 & 88731 & \\
\hline & $41-50$ & 4,2738 &, 75252 & \\
\hline & 51 ve üzeri & 4,0000 &, 47140 & \\
\hline \multirow{4}{*}{$\begin{array}{l}\text { Normatif } \\
\text { Bağl1lık }\end{array}$} & $20-30$ & 3,2772 &, 74950 & \multirow{4}{*}{,007 } \\
\hline & $31-40$ & 3,4000 & 85034 & \\
\hline & $41-50$ & 3,8929 & 69532 & \\
\hline & 51 ve üzeri & 4,1250 &, 17678 & \\
\hline
\end{tabular}


Özel Banka Calıșanlarının Örgütsel Bağllık Düzeyleri

\begin{tabular}{|c|c|c|c|c|}
\hline \multirow{4}{*}{ Devam Bağlılı̆̆ } & $20-30$ & 3,0054 & ,76465 & \multirow{4}{*}{,434 } \\
\hline & $31-40$ & 2,9786 &, 81240 & \\
\hline & $41-50$ & 2,7054 & 1,00474 & \\
\hline & 51 ve üzeri & 2,8750 &, 53033 & \\
\hline Boyut & Eğitim & Ortalama & $\begin{array}{l}\text { Standart } \\
\text { Sapma }\end{array}$ & $\operatorname{Sig}(p)$ \\
\hline \multirow{4}{*}{$\begin{array}{l}\text { Duygusal } \\
\text { Bağl1lik }\end{array}$} & Lise & 3,3000 & 88622 & \multirow[b]{4}{*}{0,024} \\
\hline & Yüksekokul & 3,9630 & 1,12045 & \\
\hline & Lisans & 3,7634 & 87689 & \\
\hline & Lisansüstü & 4,3333 & ,69722 & \\
\hline \multirow{4}{*}{$\begin{array}{l}\text { Normatif } \\
\text { Bağl1lık }\end{array}$} & Lise & 3,2250 &, 77332 & \multirow{4}{*}{0,071} \\
\hline & Yüksekokul & 3,7222 & 1,11415 & \\
\hline & Lisans & 3,4318 &, 80611 & \\
\hline & Lisansüstü & 4,0278 & ,64280 & \\
\hline \multirow{4}{*}{ Devam Bağlılığı } & Lise & 3,5125 & ,67607 & \multirow[b]{4}{*}{0,001} \\
\hline & Yüksekokul & 3,4444 & 86402 & \\
\hline & Lisans & 2,8444 & 82266 & \\
\hline & Lisansüstü & 2,7222 & ,61802 & \\
\hline Boyut & Unvan & Ortalama & $\begin{array}{l}\text { Standart } \\
\text { Sapma } \\
\end{array}$ & $\operatorname{Sig}(p)$ \\
\hline \multirow{7}{*}{$\begin{array}{l}\text { Duygusal } \\
\text { Bağl1lik }\end{array}$} & $\begin{array}{l}\text { Asistan } \\
\text { Servis } \\
\text { Görevlisi } \\
\end{array}$ & 3,4826 & ,90877 & \multirow{7}{*}{0,035} \\
\hline & $\begin{array}{l}\text { Asistan } \\
\text { Servis } \\
\text { Yetkilisi } \\
\end{array}$ & 3,7865 & ,96835 & \\
\hline & $\begin{array}{l}\text { Uzman } \\
\text { Yardımcisı }\end{array}$ & 3,9167 & 1,23603 & \\
\hline & Uzman & 3,8333 & 84254 & \\
\hline & $\begin{array}{l}\text { Yönetmen } \\
\text { Yardımcıs1 }\end{array}$ & 3,8542 & ,69385 & \\
\hline & Yönetmen & 4,2424 &, 75018 & \\
\hline & Müdür & 3,8462 & ,95612 & \\
\hline \multirow{3}{*}{$\begin{array}{l}\text { Normatif } \\
\text { Bağl1lik }\end{array}$} & $\begin{array}{l}\text { Asistan } \\
\text { Servis } \\
\text { Görevlisi }\end{array}$ & 3,2463 &, 75440 & \multirow[b]{3}{*}{0,125} \\
\hline & $\begin{array}{l}\text { Asistan } \\
\text { Servis } \\
\text { Yetkilisi }\end{array}$ & 3,3906 &, 85652 & \\
\hline & $\begin{array}{l}\text { Uzman } \\
\text { Yardımcisı }\end{array}$ & 3,8125 & 1,14337 & \\
\hline
\end{tabular}


Özel Banka Calıșanlarının Örgütsel Bağlılık Düzevleri

\begin{tabular}{|c|c|c|c|c|}
\hline & Uzman & 3,5263 & ,62857 & \\
\hline & $\begin{array}{l}\text { Yönetmen } \\
\text { Yardımcis1 }\end{array}$ & 3.6250 & .85338 & \\
\hline & Yönetmen & 3,6591 & ,93077 & \\
\hline & Müdür & 3,7885 & 84685 & \multirow[b]{8}{*}{0,038} \\
\hline \multirow{7}{*}{ Devam Bağlılığ } & $\begin{array}{l}\text { Asistan } \\
\text { Servis } \\
\text { Görevlisi }\end{array}$ & 3,1493 & ,70585 & \\
\hline & $\begin{array}{l}\text { Asistan } \\
\text { Servis } \\
\text { Yetkilisi }\end{array}$ & 3,0469 & ,89676 & \\
\hline & $\begin{array}{l}\text { Uzman } \\
\text { Yardımcis1 }\end{array}$ & 2,5000 & ,45644 & \\
\hline & Uzman & 2,4605 & ,63609 & \\
\hline & $\begin{array}{l}\text { Yönetmen } \\
\text { Yardımcısı } \\
\end{array}$ & 2,8333 & ,86811 & \\
\hline & Yönetmen & 2,8295 & ,96482 & \\
\hline & Müdür & 2,8462 & 1,02844 & \\
\hline Boyut & $\begin{array}{l}\text { Çalış̧ma } \\
\text { Süresi } \\
\end{array}$ & Ortalama & $\begin{array}{l}\text { Standart } \\
\text { Sapma }\end{array}$ & $\operatorname{Sig}(p)$ \\
\hline \multirow{4}{*}{$\begin{array}{l}\text { Duygusal } \\
\text { Bağl1lık }\end{array}$} & 1 Yildan az & 3,1852 & 1,19735 & \multirow[b]{4}{*}{0,115} \\
\hline & $1-5 \mathrm{y} 1 \mathrm{l}$ & 3,5729 & 86957 & \\
\hline & $6-10 \mathrm{y} 11$ & 3,8528 &, 72167 & \\
\hline & $\begin{array}{l}10 \text { y1ldan } \\
\text { fazla }\end{array}$ & 3,8083 &, 97547 & \\
\hline \multirow{4}{*}{$\begin{array}{l}\text { Normatif } \\
\text { Bağll11k }\end{array}$} & 1 Yildan az & 3,0000 & ,69597 & \multirow[b]{4}{*}{0,110} \\
\hline & $1-5 \mathrm{y} 11$ & 3,2734 & ,88982 & \\
\hline & $6-10 \mathrm{y} 11$ & 3,5917 & ,66538 & \\
\hline & $\begin{array}{l}10 \text { yldan } \\
\text { fazla }\end{array}$ & 3,4719 & ,89301 & \\
\hline \multirow{4}{*}{ Devam Bağlılığı } & 1 Yoldan az & 3,3056 & ,95015 & \multirow{4}{*}{0,022} \\
\hline & $1-5$ yil & 3,0703 &, 85721 & \\
\hline & 6-10 y1l & 2,6833 & 67940 & \\
\hline & $\begin{array}{l}10 \text { yildan } \\
\text { fazla }\end{array}$ & 3,0438 & ,87581 & \\
\hline
\end{tabular}




\section{Özel Banka Calıșanlarının Örgütsel Bağlılık Düzeyleri}

\section{Sonuç ve Öneriler}

Günümüzde küreselleşme, rekabet ve teknolojideki yenilikler örgütler için birçok zorluk getirmekte ve örgütlerin etkin ve verimli olma, varlığını sürdürme ve rekabet üstünlüğü sağlama gerekliliğini ortaya çıkarmaktadır. Bu anlamda örgütlerin sayılan bu hedefleri yerine getirme noktasında insan kaynağına gereken önemi vermesi ve örgüte olan bağlılıklarını artırması gerekmektedir. Çünkü yüksek bağlılığa sahip çalışanlar örgütün hedef ve amaçlarını benimsemekte, hedef ve amaçların gerçekleşmesi için büyük çaba göstermekte, örgütte kalmak için güçlü bir istek duymaktadır. $\mathrm{Bu}$ anlamda örgütsel bağlllı̆̆ artırmak için örgüte ve en önemlisi yöneticilere büyük görev düşmektedir.

Araştırma sonuçlarına göre, duygusal bağll1ık $(\bar{x}=3,75)$ ve normatif bağl1lığa $(\bar{x}=3,48)$ ilişkin ortalama düzeyleri yüksek, devam bağl1lı̆g $(\bar{x}=2,95)$ için orta düzeydedir. Bu da çalışanların örgütte kalmak için güçlü bir istek duymasını ve örgüte olan duygusal bağını ifade eden duygusal bağlılığın ve çalışanın çalıştığı örgüte karşı kendini sorumlu hissetmesini ifade eden normatif bağlılığın yüksek düzeyde; çalışanın örgütten ayrılma durumunda katlanacağı maliyetleri kaybetme düşüncesi ile örgütte kalmasını ifade eden devam bağlılığının ise katılımcılarda orta düzeyde olduğunu göstermektedir.

Çalışmada üzerinde durulan bir konu, örgütsel bağll1ık boyutlarının demografik değişkenlere göre farklılık gösterip göstermediğinin tespit edilmesidir. $\mathrm{Bu}$ anlamda örgütsel bağllıkla ilgili değerler, cinsiyete göre farkl1lık göstermemekte; medeni duruma, yaşa, eğitim durumuna, unvana ve çalışma süresine göre farklılık göstermektedir. Yapılan analiz sonucuna göre, evli olan çalışanların duygusal bağlılıkları bekarlara göre daha yüksektir. Bu da evli çalışanların bekar çalışanlarla karşılaştırıldığında kurumun değer ve hedeflerini daha çok benimseyerek görevlerini yerine getirdiklerini, kuruma olan aidiyet duygusunun daha fazla olduğunu göstermektedir. Gündoğan'ın (2009) banka çalışanları üzerinde yaptığı araştırma sonuçları da bunu desteklemektedir. Ayrıca, 41-50 yaş grubunun duygusal bağll1ık ve normatif bağl11ık ortalamasının 20-30 yaş grubuna ve 31-40 yaş grubuna göre daha yüksek olduğu sonucuna ulaşılmıştır. Gündoğan'ın (2009) çalışması da bu sonucu desteklemektedir. Araştırmada ayrıca, eğitim düzeyi lisansüstü olan katılımcıların duygusal bağlılık algılarının eğitim düzeyi lise olan çalışanlara göre daha yüksek olduğu sonucuna ulaşılmış̧ır. Yapılan bazı araştırmalar ile de (Gülova ve Demirsoy, 2012, Salami, 2008) eğitim düzeyi artıkça çalışanların duygusal bağllı̆ı̆ının arttığı sonucuna ulaşılmıştır. Çünkü yüksek öğrenim görmüş kalifiye insanlar daha yüksek rütbeye sahip oldukları ve daha fazla sorumluluk aldıkları için örgüte karşı çok daha fazla bağlı olmaktadırlar. Ayrıca, araştırmada eğitim düzeyi lise olan katılımcıların ise eğitim düzeyi lisans olan katılımcılar ile kıyaslandığında devam bağlılığı daha yüksek olduğu sonucuna ulaşılmıştır. Çöl ve Gül (2005) de yaptığı araştırma ile eğitim düzeyi yükseldikçe devam bağlılığının azaldığı sonucuna ulaşmıştır. Çünkü eğitim düzeyi yüksek olan çalışanların kendilerine olan güvenleri artmakta ve örgütte kalmaya istekten ziyade zorunlu oldukları fikrinden doğan devam bağlılığı azalmaktadır. Ayrıca, asistan servis görevlisinin yönetmen ile kıyaslandığında duygusal bağlılığının daha düşük, devam 


\section{Özel Banka Calıșanlarının Örgütsel Bağlılık Düzeyleri}

bağlılığının ise daha yüksek olduğu sonucuna ulaşılmıştır. Bu anlamda bankaların asistan servis görevlerinin duygusal bağlılıklarını artıracak girişimlerde bulunmaları gerekmektedir. Özellikle asistan servis görevlilerin devam bağlllı̆̆ının yüksekliği göz önünde bulundurulduğunda bankada istekten ziyade zorunluluktan kaldığı anlaşılmaktadır. Bu noktada banka yöneticilerine görev düşmekte ve sıcak, samimi bir örgüt iklimini oluşturmaları gerekmektedir. Son olarak, çalışma süresi 1 yıldan az olan çalışanların devam bağlığının en yüksek, çalışma süresi 6-10 yıl aralığında olan çalışanların ise devam bağlılığının en düşük olduğu tespit edilmiştir.

\section{KAYNAKÇA}

Allen, N. J. and Meyer, J. P. (1990). "The Measurement and Antecedents of Affective, Continuance and Normative Commitment to the Organization.", Journal of Occupational Psychology, 63/1, s.1-18.

Balay, R.(2014).Yönetici ve Öğretmenlerde Örgütsel Bağlllık, Pegem Akademi, Ankara.

Becker, H. S. (1960). "Notes on the Concept of Commitment", American Journal of Sociology, 66/1, s.32-40.

Chen, L. T. , Chen, C. W. and Chen, C. Y. (2010). "Are Educational Background and Gender Moderator Variables for Leadership, Satisfaction and Organizational Commitment?”, African Journal of Business Management, 4/2, s.248-261.

Çelik, C. (2008). Relationship of Organizational Commitment and Job Satisfaction: A Field Study of Tax Office Employees, International Conference on Management and Economics, s.138-155.

Çöl, G. ve Gül, H. (2005). "Kişisel Özelliklerin Örgütsel Bağlllık Üzerine Etkileri ve Kamu Üniversitelerinde Bir Uygulama”, Atatürk Üniversitesi İktisadi ve İdari Bilimler Dergisi, 19/1, s.291-306.

Eren, E. (2012). Örgütsel Davranış ve Yönetim Psikolojisi, 13. Basım, Beta Yayınevi, İstanbul.

Gündoğan, T. (2009). Örgütsel Bağllllk: Türkiye Cumhuriyet Merkez Bankası Uygulaması, Türkiye Cumhuriyet Merkez Bankası İnsan Kaynakları Genel Müdürlüğü, Uzmanlık Yeterlilik Tezi, Ankara.

Güney, S. (ed.), (2001). Yönetim ve Organizasyon, 1. Basım, Nobel Yayın Dağıtım, Ankara.

Meyer, J. P., and Allen, N. J. (1984). "Testing the" Side-Bet Theory" of Organizational Commitment: Some Methodological Considerations", Journal of Applied Psychology, 69/3, s.372.

Meyer, J. P., Stanley, L. J. and Parfyonova, N. M. (2012). "Employee Commitment in Context: The Nature and Implication of Commitment Profiles, Journal of Vocational Behavior, 80/1, s.1-16. 


\section{Özel Banka Calıșanlarının Örgütsel Bağlılık Düzeyleri}

Mowday, R. T. , Steers, R. M. and Porter, L. W. (1979). "The Measurement of Organizational Commitment", Journal of Vocational Behavior, 14/2, s.224247.

Özdevecioğlu, M. (2003). “Algılanan Örgütsel Destek ile Örgütsel Bağlllık Arasındaki İlişkilerin Belirlenmesine Yönelik Bir Araştırma”, Dokuz Eylül Üniversitesi İktisadi ve İdari Bilimler Fakültesi Dergisi, 18/2, s.113-130.

Reichers, A. E. (1985). "A Review and Reconceptialization of Organizational Commitment", The Academy of Management Review, 10/3, s.465-476.

Robbins, S. ve Timothy J. (2012). Örgütsel Davranış, (Çev: İnci Erdem), 14. Basım, Nobel Yayınevi, İstanbul.

Salami, S. O. (2008). "Demographic and Psychological Factors Predicting Organizational Commitment Among Industrial Workers", Anthropologist, 10/1, s.31-38.

Sevinç, İ. ve Şahin, A. (2012). "Kamu Çalışanlarının Örgütsel Bağlılığı Karşılaştırmalı Bir Çalışma", Maliye Dergisi, 162, s.266-281.

Tett, R. P. and Meyer, J. P. (1993). "Job Satisfaction, Organizational Commitment, Turnover Intention and Turnover: Path Analysis Based on Meta Analytic Findings", Personal Psychology, 46/2, s.259-293.

Wasti, S. A. (2000). Örgütsel Bağl1lığı Belirleyen Evrensel ve Kültürel Etmenler: Türk Kültürüne bir Bakış, Türkiye'de Yönetim, Liderlik ve İnsan Kaynaklarl Uygulamalarl, Türk Psikologlar Derneği Yayınları, No:21, Ankara. 